allowing Williams to collect on the GE options. This helped to finance his move to OSU, where the academic salary is about a third of the salary and incentive plan he received at GE.
With his stock options secured, Williams became a full professor again at the age of $60 \frac{1}{2}$. "If you are leaving industry and you are concerned about compensation, then you probably shouldn't be doing it," he says.

\title{
Georgia realizes the commercial potential of science
}

$\mathrm{S}$ cience in the state of Georgia is undergoing a dramatic transformation as stronger links are forged between business and academia. The organization behind this work is the Georgia Research Alliance (GRA), which has brought the state's government, business community and research universities into a partnership that enhances scientific development and subsequent commercialization. "In Georgia, we believe that our research universities are powerful engines for economic development," says GRA president Michael Cassidy.

The GRA offers resources to foster, and perhaps accelerate, Georgia's economic development through activities such as helping to finance new university buildings. For example, Clifton Baile, a GRA eminent scholar in agricultural biotechnology at the University of Georgia, has been involved in a \$28 million biotechnology initiative. This covers five different sites, the largest of which is a $\$ 15$ million building at the University of Georgia. This new facility has areas for scientific discovery and product commercialization, and a third of the building is available for lease to start-up companies.

The GRA technology partnership programme gives support to universities that match commercial money for start-up activities. Funding from the GRA is also available for developing core laboratory facilities, such as a $\$ 16$ million, three-year proposal for laboratories in genomics and proteomics. In addition, the GRA supplies loaned equipment to start-ups within university incubators.

\section{Wanted: eminent scholars}

The GRA also provides funding for eminent scholars and endowed chairs in the state's universities. This is an especially effective contribution, says Baile, as it is used exclusively to attract talent and technology from outside Georgia. One such position is now being advertised in the area of animal genomics, and specifically designed facilities are part of the package.

Baile, who worked for 13 years in industrial research at Monsanto (see box), says that the eminent scholar programme was one of the mechanisms used to attract Steve Stice to the University of Georgia in 1998. Baile recruited him from Advanced Cell Technolo- gies, a company that Stice co-founded while an adjunct professor at the University of Massachusetts in Amherst.

In addition to accepting the $\$ 1.5$ million endowed chair, Stice is employed by ProLinia, one of the start-up companies supported by the university and the GRA. This unusual dual appointment is structured so that Stice spends 51 per cent of his time as a professor, with the rest spent at ProLinia. While in Massachusetts, Stice and his senior professor James Robl pioneered the development of cloned transgenic animals. ProLinia was formed to commercialize the use of cloning and transgenics for food-producing animals.

According to Baile, the backing of upper management at the university has made a great difference to the overall success of the GRA initiative. For example, University of
Georgia provost Karen Holbrook works closely with Baile and is a strong advocate of this kind of activity, he says. In a previous position as vice-president of research at the University of Florida, Holbrook helped build an incubator facility for start-ups. Stice has found that faculty is also receptive to this kind of approach, and with the president, provost and dean driving it forwards, he hopes that it will be used as a model for future recruitment of eminent scholars to endowed chairs.

This system works, says Stice, because it is structured to optimize the success of both the university and the company. For example, "I'm working on new ways of cloning animals, and I don't have to think about whether I'm working for the company or the university today", he says. All of the intellectual property goes to the university, and the company that is sponsoring the research licenses it from the university.

This is also an exceptional environment for students, most of whom will end up in industry, says Stice. Consequently, it is important for them to get an early taste of what it is like to work in an industrial setting. In this case, that company might be located in the next lab or down the hall. "Obviously, industry is not right for everyone," he says, but in this environment students are able to make more informed career choices.

Brendan Horton is a freelance science journalist. e-mail:b.horton@naturedc.com

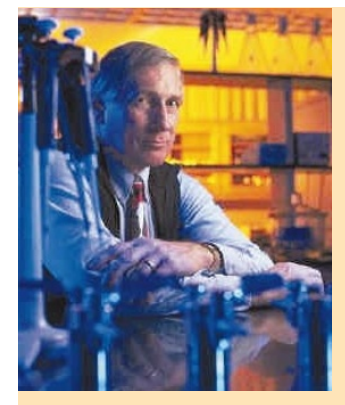
The importance of experience Few researchers have spent as much time in industry as Clifton Baile and still have enough academic accomplishments to re-enter academia as a professor. Baile may have established his academic credentials before entering industry by working at Harvard University and the University of Pennsylvania on the control of energy balance in animals but, unusually, he was able to continue this work while a director of research at Monsanto. At Monsanto, Baile was one of 130 fellows among the company's 5,000 scientists. "In the fellows programme, I had a responsibility, or a privilege, to continue my scientific interests," he says.

After 13 years of directing research programmes for up to 375 people at Monsanto - during which time he oversaw the development of the controversial drug BST (bovine somatotropin) - Baile was ready to do something else. "That was not just science, and it wasn't just drug development, it was a political war," he says. When the opportunity arose, he took a retirement package from Monsanto that gave him years of financial security over and above what he had anticipated.

When he moved to the University of Georgia he was attracted by the chance to work in the vice-president's office for research as a full professor. Baile thought this set up would be better than being allied to a particular department as it would allow him to be involved in the overall development of research at the university.

"What turned out to be really attractive, and should have been the main reason for coming to Georgia, was the GRA, but I didn't really understand it when I made my decision," says Baile. He expected to be involved with technology transfer, owing to his considerable experience in the commercial sector, but he did not realize that the GRA would provide so much supporting infrastructure. According to Baile, the GRA makes the University of Georgia unusual, if not unique, in what it can offer someone like him.

As a result, Baile now has a very different relationship with the university. "I am a tenured professor, but I'm probably the only tenured professor in the state who is non-salaried," he says. He joined the university without a requirement for salary because he wanted the freedom to use the infrastructure to develop universitycommercial relationships and businesses. He has students who are part of his contract with the university and he is responsible for a floor of the animal-science building and its equipment. This floor also houses several of the companies with which Baile works closely. It is unusual and beneficial for students to have exposure to advisers and mentors who are closely tied to the commercialization of scientific discovery, Baile says. 